Regina Grafe*

\title{
Empires of Charity: Imperial Legitimacy and Profitable Charity in Colonial Spanish America
}

https://doi.org/10.1515/ngs-2018-0027

\begin{abstract}
This article investigates the institutionalization and the practices of charity that sustained imperial rule in the early modern Spanish Empire. The article proposes that the polycentric Spanish Empire of the 16th to 18th centuries faced a fundamental challenge in terms of justifying the extension of power beyond its original territory of legitimization through custom and (invented) history. This challenge was dealt with through recourse to an ideology of good governance in corporate society. It institutionalized differences across race/ caste, urban/rural, professional, gender and other categories in collectives that held part of a layered and fragmented sovereignty. But unlike its modern successor empires and nation states, it did not have to rely systematically on the essentialization of difference. Thus, good governance could legitimize the extension of hegemony beyond the original territory of political legitimization and charity played a central role in this. A material caritative complex sui generis linked the moral economy of charity, which legitimized local elites, with their own financing needs and those of the imperial polity via the financial acumen of religious and charitable institutions.
\end{abstract}

Keywords: legitimacy, charity, empire, institutions, sovereignty, race

The arrival of global history as a mainstream field has posed a particular challenge to the study of empire. Some have criticized global history for being little more than imperial history in a new disguise, and undoubtedly some traditional imperial historians have tried to jump on the bandwagon of global history. ${ }^{1}$ Nevertheless, the new global history approaches have served to sharpen historians' sensibility to the pitfalls of century-old methodological centrisms (be they Euro-, Sino-, Christian-, Islamic-). And they promise to emancipate the field from its problematic roots as "national" imperial histories of the British,

1 Durba Ghosh, “Another Set of Imperial Turns?” American Historical Review 117, 3 (2012).

*Corresponding author: Regina Grafe, Dept of History, European University Institute, Florence, Italy, E-mail: regina.grafe@eui.eu 
French, Portuguese, or any other empire. ${ }^{2}$ Global approaches such as reciprocal comparisons have helped us understand the practices and institutions that underpinned imperial hegemony in more sophisticated ways. ${ }^{3}$ The complex interactions of conquerors and conquered that resulted in assemblages of cultures and structures of social, political, and economic governance which originated as much in annexed territories as in imperial capitals have come into sharper relief. ${ }^{4}$ Questions of power, legitimacy of rule, and sovereignty in imperial formations turned out to be much more complicated than national historiographies of the post-colonial period would have allowed for. ${ }^{5}$

The idea of empires of charity sounds like an oxymoron. Imperial practices are more often linked to conquest, conversion, extraction, and self-interest while charity is usually analyzed within a frame of concern for the weak, religious observance, and altruism. Drawing on early modern Spain's American Empire as a case study, the first section of the article addresses the larger question of how to define an empire in the light of recent historiography, and the role of charity as an imperial practice. The second section looks at the governance structures and material well-being in Spanish America as a way to contextualize material conditions for and the purpose of charity. Finally, section three shows that charity's contribution to the legitimacy of imperial domination in Spanish America went far beyond concerns for the poor and social peace or the redemption of givers' sins. In Spanish America charity became part of the financial architecture of the empire that linked subjects of the Monarchy in a complex set of dependencies across social strata. The collapse of this architecture threatened the well-being of very large sections of society thus helping to sustain imperial rule. The significance of charity was therefore not restricted to the realm of welfare and religious practice. Instead it was a fundamental part of the repertoire of imperial practices.

2 Richard Drayton and David Motadel, "Discussion: The Futures of Global History," Journal of Global History 13, 1 (2018).

3 Joseph E. Inikori, Africans and the Industrial Revolution in England: A Study in International Trade and Economic Development (New York: Cambridge University, 2002), Gareth Austin, "Reciprocal Comparison and African History: Tackling Conceptual Eurocentrism in the Study of Africa's Economic Past” African studies review 50, 3 (2007).

4 Serge Gruzinski, The Mestizo Mind: The Intellectual Dynamics of Colonization and Globalization (New York; London: Routledge, 2002).

5 See e. g. Lauren A. Benton, A Search for Sovereignty: Law and Geography in European Empires, 1400-1900 (Cambridge; New York: Cambridge University Press, 2010), Saliha Belmessous, Native Claims: Indigenous Law against Empire, 1500-1920 (Oxford; New York: Oxford University Press, 2012). 
The point of departure for this discussion must necessarily be what we mean when we say empire. The many attempts at defining empire in recent publications illustrate vividly that there is nothing obvious about this question. ${ }^{6}$ Most start from a seemingly simple categorization, which however is then followed by a long list of qualifying characteristics such as distinctions between empires of settlement and exploitation or contiguous and overseas ones. A good starting point could be the helpful definition suggested by Burbank and Cooper in 2010, that "Empires are large political units, expansionist or with a memory of power extended over space, polities that maintain distinction and hierarchy as they incorporate new people." They add that empires rely on "the externalization of sources of wealth." The elements contained are those that feature in most definitions: large size and an expansionary drive at least in part as a means of acquiring extractable wealth from incorporated territories. But these polities also tended to be "empires of difference" because they lacked the strong homogenizing ambition of the nation state of the $19^{\text {th }}$ and $20^{\text {th }}$ centuries and were overall more tolerating of religious, cultural, linguistic, and institutional diversity. ${ }^{8}$

As parsimonious as this definition is, I will argue in the rest of the article that it still includes one descriptor that is historically not a necessary condition for empire, namely that empires strove to extract wealth from conquered territories. I posit that empires are not necessarily associated with the extraction of wealth; indeed extraction potentially endangered imperial survival as we will see. ${ }^{9}$ My working definition of imperial formations will thus be even more frugal: Empires are polities that extend power beyond the territory of original political legitimization. This definition concentrates attention on what I consider the fundamental issue of political legitimacy. What all empires have in common

6 See e.g. Jürgen Osterhammel, Colonialism: A Theoretical Overview, 2nd ed. (Princeton: Markus Wiener Publishers, 2005); Frederick Cooper, Colonialism in Question: Theory, Knowledge, History (Berkeley: University of California Press, 2005); Tom Toelle, "Early Modern Empires: An Introduction to the Recent Literature," in H-Soz-Kult, 20.04.2018, < www.hsozkult. de/literaturereview/id/forschungsberichte-2021> (2018).

7 Jane Burbank and Frederick Cooper, Empires in World History: Power and the Politics of Difference (Princeton, N.J.: Princeton University Press, 2010).

8 Ibid.; Karen Barkey, Empire of Difference: The Ottomans in Comparative Perspective (Cambridge; New York: Cambridge University Press, 2008).

9 Regina Grafe and Alejandra Irigoin, "Negotiating Power: Fiscal Constraints and Financial Development in Early Modern Spain and the Spanish Empire," in Questioning Credible Commitment, ed. D'Maris Coffman (Cambridge: Cambridge University Press and Winton Centre for Financial History, 2013). 
is a problem of legitimization: because they extended their spatial reach they could not rely on tradition and custom to legitimize rule via established practices and institutions. The expansionary nature of empires reduced the scope for a legitimizing narrative of the kind that simply rewrote history to make rule appear as existing from time immemorial because territory and political community were ostensibly non congruent. That deprived empires of the most powerful ideological basis of political rule: (invented) history.

My emphasis on the expansion of territory beyond the spatial boundaries of original political legitimation should not be mistaken to imply that empires relied particularly strongly on notions of territoriality. It has rightly been argued that early modern empires more often than other polities had only hazy ideas of exact boundaries and few ambitions and less means to define them. ${ }^{10}$ As Herzog has shown the boundaries of European empires outside Europe were drawn not in the metropolis but in situ in negotiations that involved Euro-descendants and native populations, albeit often in skewed power relations. ${ }^{11}$ Nevertheless, early modern empires clearly laid claim, which they could not justify in terms of customary practices, to new territories. That set them apart from other contemporary polities such as city states, urban alliances, princely or republican territorial states, or chiefdoms for that matter. Empires were so often characterized by fluid claims to spaces on their margins precisely because they could not rely on custom and history for their claims. Thus the issue always revolved around the legitimacy of rule and only secondarily around concrete borders.

Empires were therefore characterized by a set of practices of power, a repertoire of strategies needed to justify the extension of power both ex-ante and ex-post. To put it another way, empires needed an ideology of power that rationalized why conquest was a justified means of changing the structures of political power in a conquered territory and, once conquest has occurred, to legitimize the continued control over this territory. ${ }^{12}$ Early modern authors took it for granted that conquest was the easy bit, maintaining hegemony was the tricky part. ${ }^{13}$ With very limited repressive capacity at their disposal early modern empires could not rely on violence alone but had to create a narrative of "good governance." Subject peoples in turn used demands for what one of the first

10 Toelle, "Early Modern Empires: An Introduction to the Recent Literature."

11 Tamar Herzog, Frontiers of Possession: Spain and Portugal in Europe and the Americas (Cambridge: Harvard Univ. Press, 2015).

12 Walter Mignolo, Local Histories/Global Designs Coloniality, Subaltern Knowledges, and Border Thinking (Princeton, NJ: Princeton University Press, 2012).

13 Anthony Pagden, Lords of the World: Ideologies of Empire in Spain, Britain and France, C.1500-1800 (New Haven: 1995), ch. 4. 
indigenous chroniclers of the Andes region called "buen gobierno" as a powerful tool of negotiation. ${ }^{14}$ Describing Inca or Mexica (Aztec) rule as tyrannical, and therefore the conquest of Peru or Mexico as the liberation of subject people, could serve to some extent to justify conquest. ${ }^{15}$ But the struggles of Spanish jurists to find excuses for the conquest of the Americas even within their own legal world (never mind that of the conquered peoples) were real. Even the famous requerimiento, which Spanish conquerors read to unsuspecting indigenous populations to give them a choice of subjugation or war, offered "to receive you [the indigenous] with love and charity" as part of its rationalization for conquest. ${ }^{16}$ Far away from the American shores the tortured arguments of Spanish scholastics that Indians had denied Spaniards their ius perigrinandi, the right to travel (and mission), were understood to be a weak rationalization for conquest to begin with. Worse still, they certainly did not suffice to legitimate continued rule over American subject populations even in the minds of most contemporary Spanish lawyers and churchmen. ${ }^{17}$

One way to ease the burden of legitimization of imperial rule was political practices that allowed for the location of power to be decentralized. Imperial history was in the past almost invariably conceptualized as a center-periphery dynamic. Historiographies in former imperial "centers" went from analyzing glorious colonial pasts to trying to understand the post-colonial heritage of modern European nation states in the Netherlands, Spain, or elsewhere. At the same time, for nationalist post-independence historiographies in former colonies the "alienness" of remote rule from a far-away metropolis was a fundamental piece of emancipatory language. However, recent research shows that imperial formations were sometimes very decentralized, relying heavily on intermediate power centers and elites. In the case of the Iberian empires, many now conceive of these polities as polycentric, that is a complex web of decision-making centers

14 Felipe Guamán Poma de Ayala and Rolena Adorno, Poma de Ayala: El Primer Nueva Corónica Y Buen Gobierno (Copenhagen: Museum Tusculanum Press, University of Copenhagen, 2002), Rolena Adorno Guaman Poma: Writing and Resistance in Colonial Peru (Austin, Tex.: Univ. of Texas Press, 2000).

15 Pedro Sarmiento de Gamboa, Brian S. Bauer, and Vania Smith-Oka, The History of the Incas (Austin: University of Texas Press, 2007 [1572]). For Mexico see Cortes' description of Mexica tyranny, Hernán Cortés, Anthony Pagden, and John Huxtable Elliott, Hernan Cortes: Letters from Mexico (New Haven, CT; London: Yale University Press, 2001).

16 Juan López de Palacios Rubios, “Notificación Y Requerimiento Que Se Ha Dado De Hacer a Los Moradores De Las Islas En Tierra Firme Del Mar Océano Que Aún No Están Sujetos a Nuestro Señor" (1513).

17 Annabel S. Brett, Changes of State: Nature and the Limits of the City in Early Modern Natural Law (Princeton, N.J.: Princeton University Press, 2011), pp.26ff; Tamar Herzog, A Short History of European Law: The Last Two and a Half Millennia (Cambridge MA.: Harvard University Press 2018). 
with relatively flat hierarchies between them. ${ }^{18}$ Comparative histories of empire have shown that they could take different shapes along a continuum from centralizing, to power devolving, and polycentric with the exact shape of each historical example hotly debated. As I have shown elsewhere polycentric structures went a long way to turn imperial subjects into stakeholders of empire who had an interest in its survival. By incorporating notions of urban or territorial quasi sovereign rights into the wider web of empire newly conquered or founded cities could be co-opted into a network structure of sovereignty. One particularly famous example of this process was the alliance between Tlaxcala and the Spanish, which reverberated in negotiations for special status of the former from the $16^{\text {th }}$ to the $19^{\text {th }}$ centuries. ${ }^{19}$

The relationship between power, sovereignty, and legitimacy of rule in early modern empires becomes clearer if we compare them with their $19^{\text {th }}$ and $20^{\text {th }}$ century successors. Imperial political power depended on notions of sovereignty to establish legitimacy until well into the $19^{\text {th }}$ century. Only by the $20^{\text {th }}$ century technologies of coercion had been perfected sufficiently to make it viable for some empires to rely almost exclusively on repression - German rule in Namibia comes to mind. The increased technical and administrative capacities of imperial states in the $19^{\text {th }}$ and $20^{\text {th }}$ centuries were certainly important. But I would argue that the more fundamental rupture had to do with changing conceptions of sovereignty. From the $19^{\text {th }}$ century onwards sovereignty began to be understood as indivisible. This was a genuinely new conception, which truth be told only translated into coherent legal, administrative, and political practices over a long period of time. Legal pluralism, the co-existence of more or less competitive legal normative orders persisted in reality and in many former colonial countries it persists to this day. But once sovereignty was understood as indivisible legal pluralism began to be normatively problematic. Early modern understandings of sovereignty, by contrast, had been fragmented, overlapping, and layered

18 Pedro Cardim et al., Polycentric Monarchies: How Did Early Modern Spain and Portugal Achieve and Maintain a Global Hegemony? (Eastbourne; Portland, Or.: Sussex Academic Press, 2012); Regina Grafe, "Tyrannie À Distance: La Construction De L'état Polycentrique Et Les Systèmes Fiscaux En Espagne (1650-1800),” in Ressources Publiques Et Construction Étatique En Europe, ed. Katia Beguin (Paris: (IGPDE), Ministère des Finances et des Comptes Publics, Ministère de l'Economie, de l'Industrie et du Numérique, 2015).

19 See for example documents detailing negotiations between the Tlaxcala Indians and the Spanish monarchy from the $16^{\text {th }}$ to the $19^{\text {th }}$ century, Newberry Library, VAULT Ayer MS 1162 . See also Ana Díaz Serrano, "La Doble Orilla. El Modelo Político De La Monarquía Hispánica Desde Una Perspectiva Comparada. Los Cabildos De Murcia Y Tlaxcala Durante El Siglo Xvi,” in Las Monarquías Española Y Francesa, Siglos Xvi-Xviii: ¿Dos Modelos Políticos?, ed. Anne Dubet and José Javier Ruiz Ibáñez (Madrid: Casa de Velázquez, 2010). 
between corporate groups and "historic" territories. Legal pluralism was therefore the norm and unproblematic. ${ }^{20}$

These fundamentally different conceptions of sovereignty mattered because they delimited the strategies to legitimize rule. Early modern forms of political representation were mediated via the corporate status of towns, guilds, the Church, the Estates, free and unfree status, chartered companies, or ethnic groups such as castas in colonial Spanish America. ${ }^{21}$ The nature of such a system of shared and overlapping rights and duties of bodies, each of which was endowed with a share of sovereignty, "institutionalized" difference. But precisely because difference was institutionalized and rights and duties defined as pertaining to collectives rather than individuals there was no overriding need to essentialize them. Thus the boundaries between these categories could remain fluid, while individuals could belong to multiple and sometimes contradictory categories. How else would we understand that an Afro-descendent slave could be a master of a craft guild in colonial Lima? ${ }^{22}$ A person could be at the same time unfree, but enjoy the legal and political privileges of a senior member of a guild. The archives are full of the myriad of conflicts that this provoked. But practical problems aside, normatively there was no fundamental incompatibility.

Fragmented and layered sovereignty, which was located in a multitude of corporate bodies, enabled early modern European empires theoretically to incorporate diverse new subject populations in a way that was fundamentally identical to that applied in the original territory of political legitimization. Treating people differently according to their corporate, religious, ethnic, or territorial status paradoxically meant applying the same rules that had been at work in the original imperial territory. This facilitated the justification of expansion ex-post through an ideology of "good governance." It should be noted that this does not mean that early modern imperial societies did not engage in essentializing the differences between corporate groups in society. But the

20 Lauren A. Benton, Law and Colonial Cultures: Legal Regimes in World History, 1400-1900, Studies in Comparative World History (Cambridge, New York: Cambridge University Press, 2002). 21 Note that the language of corporate rights sometimes makes it hard to see the similarities between Anglophone contexts and continental European ones. Compare Philip J. Stern, “'Bundles of Hyphens.' Corporations as Legal Communities in the Early Modern British Empire," in Legal Pluralism and Empires, 1500-1850 (NYU Press, 2013). and Pedro Cardim, "The Representatives of Asian and American Cities at the Cortes of Portugal," in Polycentric Monarchies. How Did Early Modern Spain and Portugal Achieve and Maintain a Global Hegemony?, ed. Pedro Cardim, et al. (Sussex Academic, 2012).

22 Francisco Quiroz, Artesanos Y Manufactureros En Lima Colonial (Lima: Instituto de Estudios Peruanos, 2008). 
increasing racialization of particular groups was not necessary as a device to sustain an "empire of difference." 23

By contrast, modern political legitimacy could only be constructed via a form of unitary and homogenous representation of a body politic (which came to be defined as the nation). Difference might or might not be institutionalized in this context. Indeed, by the second third of the $20^{\text {th }}$ century most European empires struggled with attempts to maintain difference while dealing with the demand that all those governed should be equal citizens. ${ }^{24}$ But no matter if difference was turned into legal and institutional structures or not, it necessarily had to be essentialized to rationalize the unequal treatment that was incompatible with individual rights. Modern empires therefore had a much harder time to justify the extension of power beyond the original territory of legitimization through simple incorporation. ${ }^{25}$ Their only means of justifying expansion was an ideology of a "civilizing mission" based on an essentialized difference across race, religion, language, or "developmental stage." In this they resembled modern nation states; indeed one could argue that the modern nation state is a short-distance modern empire. White elites in nineteenth-century colonial Cuba and republican Peru alike turned to an increasingly racialized system of hegemony over the Afro-descendent and indigenous population. The issue was not empire or republic, but fragmented or unitary sovereignty.

This point is missed in much of the recent, otherwise very helpful, decolonial literature, which tends to back-extrapolate ahistorically from the $19^{\text {th }}$ and $20^{\text {th }}$ centuries. ${ }^{26}$ As long as sovereignty was conceptualized as layered and fragmented, roughly before 1810, the essentialization of racial difference was not a condition sine qua non for imperial expansion. The abolition of old regime forms of collective corporate rights was obviously not the sudden trigger of essentialized racism in Spanish America. Non-essentialized and essentialized

23 For a nuanced discussion see Kathryn Burns, "Unfixing Race," in Rereading the Black Legend the Discourses of Religious and Racial Difference in the Renaissance Empires, ed. Margaret Rich Greer, Walter Mignolo, and Maureen Quilligan (Chicago: University of Chicago Press, 2007).

24 Frederick Cooper, Citizenship between Empire and Nation: Remaking France and French Africa, 1945-1960 (Princeton: Princeton University Press 2014).

25 In the Hispanic case there was strictly speaking a difference between aggregation and integration but as Mazin Gomez shows the boundaries between the two concepts were in practice malleable. Oscar Mazin Gomez, "Architect of the New World: Juan De Solórzano Pereyra and the Status," in Polycentric Monarchies. How Did Early Modern Spain and Portugal Achieve and Maintain a Global Hegemony, ed. Pedro Cardim, et al. (Eastbourne: Sussex University Press, 2012).

26 See e. g. Anibal Quijano, “Coloniality of Power, Eurocentrism, and Latin America,” Nepantla. Views from South 1, 3 (2000); Mignolo, Local Histories/Global Designs. 
forms of racial discrimination had co-existed for the longest time. ${ }^{27}$ But the redefinition of sovereignty turned essentialized difference into an indispensable tool of imperial (and national) power for the first time in the $19^{\text {th }}$ century.

The difference between modern and early modern empires was thus not, as is sometimes suggested, that the latter exerted less control on their peripheries because far away territories were hard to control with early modern technologies. Instead they were a different kind of polity altogether because their understanding of sovereignty was different and that in turn determined the ideology and practices of power. Rule in the core European historic territories of the Spanish Empire and the non-European territories did not differ systematically in terms of the fragmented and layered sovereignty or indeed the practices of governance. Early modern empires were empires of difference across their European and Non-European territories. However, there was one fundamental distinction that applied only to the new non-European territories: the lack of historical legitimation for the exercise of power.

The need to justify imperial expansion and its continuation raised the bar for the notion of good governance, ultimately the only potentially credible way to legitimize the expansion of power beyond the original sphere of legitimation. This broader context is crucial in order to understand why affirming good governance was so absolutely crucial to the political practices that underpinned Spanish rule in the Americas. I suggest that without the larger frame it is impossible to comprehend the pivotal role that the maintenance of social peace played within political practices and discourses in the Hispanic World. Charity was one of the essential elements in the alignment of interest via polycentric structures and it became one of the central legitimizing imperial practices in the Hispanic world. Material sustenance for the weakest in society was one of the backbones of support for rulers and Christian notions of charity aligned almost perfectly with those practices of good governance providing an ideological frame.

The power sustaining function of charitable activities took thus specific forms in Spanish America and it is in some ways surprising that historians of welfare have only quite recently begun to pay attention to this role. The rather slim literature on welfare in Spanish America contrasts quite sharply with the intense debate about the way in which caritative activity supported rule in early modern European towns and territorial states as the historian of welfare in late colonial Mexico Arrom has pointed out. ${ }^{28}$ If - as Arrom does - one takes one's

27 Burns, "Unfixing Race."

28 For the following see Silvia Marina Arrom, Containing the Poor: The Mexico City Poor House, 1774-1871 (Durham: Duke University Press, 2000), Introduction. 
clues from the European literature for inspiration a number of potentially complementary readings emerge. One important link to consider is that between charity and social control as a collective internalization of certain norms, in Elias's terms a habitus that began to structure expectations of the give and take of charity. ${ }^{29}$ In the colonial context that meant the colonizers' social norms, which returns us to the additional need for legitimization precisely because they were not shared between colonizers and colonized ex ante, but had to become shared norms. How the weak and infirm were to be looked after - by families, religious institutions, urban corporations, or ethnic groups - would thus also become a contest over the social organization of society between pre-colonial and colonial practices.

This raises the question of how much charity should be interpreted as an oppressive practice. ${ }^{30}$ Elias saw the self-disciplining features of social control mostly as a positive force towards social cohesion. Yet, many historians of charity in Europe inspired by Foucault, and some of charitable activities in European colonies, have interpreted it as a means to discipline and mentally dominate colonial subjects, and as a suppression of individual freedom. Charity went together with religious practices and thus with conversion and its disruptive influence on native society. ${ }^{31}$ But one might ask whether this view should be equally applied in the $17^{\text {th }}$ or $18^{\text {th }}$ century Americas when a syncretic Christianity was the dominant religious practice. Either way, whether one sees charitable practices in a self-disciplining key or as part of an external disciplinary mechanism, both read charity as underpinning political stability and hegemony.

Yet, we also know that that the poor and infirm recipients of charity were hardly the docile objects of elite designs for their control. Especially historians of Catholic southern Europe and the Iberian empires have suggested that within the dominant religious ideology charity paradoxically offered some agency to the weakest in society, because the salvation of the rich depended on it. ${ }^{32}$ Corporate structure allowed for the articulation of collective defenses of the weak. The

29 Norbert Elias, Ueber Den Prozess Der Zivilisation (Frankfurt: Suhrkamp, 1976 [1939]).

30 Michel Foucault and Alan Sheridan, Discipline and Punish: The Birth of the Prison (London: Penguin, 1997).

31 In Spanish America this is a complicated two-way process. There were also those who wrote about pre-Hispanic indigenous Inkaic imperial practices of something akin to charity. Writers such as Inka Garcilaso in turn cited these as a proof of the "pre-Christian but Christian" values of indigenous peoples before the Spanish conquest and a means for the indigenous to write themselves into European history. Garcilaso de la Vega, H. V. Livermore, and Karen Spalding, Royal Commentaries of the Incas and General History of Peru (Austin: University of Texas Press, 2006). There is no equivalent for this in the case of the Mexicas.

32 Arrom, Containing the Poor. 
ubiquity of religious confraternities in Spanish America is a case in point. Confraternities were a mixture of cooperatives, which offered basic insurance for life risks, and charities, whereby the latter complemented the former. ${ }^{33}$ As Bazarte Martínez has pointed out, there was at least one confraternity for every possible member of overlapping corporate groups in early modern Mexico be they indigenous, Euro-descendants, or Afro-descendants, craft guild members, merchants, liberal professions, or royal officials and many were members of more than one, just as they were members of more than one corporate group. ${ }^{34}$

There was mixed structure of many of the institutions of welfare in the early modern Spains on either side of the Atlantic, which combined selfinterest and altruism in complex ways. Religious institutions and fraternities, hospitals and orphanages or schools, and towards the end of the colonial period poor houses all existed in a mixed economy paid for by membership and charitable giving. The colonial order provided the legal framework within which they operated. ${ }^{35}$ Especially larger urban institutions in the imperial context could serve as a means to counter some of the more extreme material effects of imperial extraction, such as they were. Charitable giving offered social and religious benefits to the colonial elite. Yet, because they existed in a mixed charitable/profit making economic space they could also result in concrete material benefits for the elites while at the same time producing some material benefits for the poor.

The remainder of this article will turn more directly to colonial Spanish America to shed some light on how exactly charity could work as a legitimizing strategy for imperial rule. While I recognize the important place charity had in religious, racial/ethnic, and gender attitudes in this article I want to instead start thinking about the issue from a more material perspective asking a very basic question. Was charity just a way in which colonial elites tried to paper over and mitigate the worst excesses of colonial extraction? Only in a second step I will wonder it the pattern of elites' considerable personal and material engagement in the provision of welfare in turn tells us something about their motivation, their hope for salvation, the control the poor, and/or more mundane and direct benefits from the system?

33 Karen Ivett Mejía Torres, Las Cofradías En El Valle De Toluca Y Su Relación Con El Crédito, 1794-1809 (El Colegio Mexiquense, 2014).

34 Alicia Bazarte Martínez, Las Cofradías De Españoles En La Ciudad De México (1526-1860) (México, D.F.: Universidad Autónoma Metropolitana, Unidad Azcapotzalco, División de Ciencias Sociales y Humanidades, 1989), 15.

35 Mejía Torres, Las Cofradias Del Valle De Toluca, pp.47ff; Bazarte Martínez, Las Cofradias, $31 \mathrm{ff}$. 


\section{II}

A first inroad into the material side of welfare provision in colonial Latin America could be to wonder how much of it was actually provided by imperial institutions. It is clear that public provision in a pre-modern context needs to be qualified, including territorial units, urban institutions, and of course religious bodies. Within the fragmented and layered nature of the polycentric polity the question can therefore only be answered in very imperfect ways. One knowable fact is what the polity as a territorial unit paid for welfare out of its budget. By the late $18^{\text {th }}$ century Spanish America was divided into more than 100 treasury districts, so-called cajas. Data for many of these have survived and were collected by TePaske and Klein in a path breaking project. ${ }^{36}$ Together with M. A. Irigoin I investigated these over a number of years in order to understand the political economy of colonial Spanish America in the $18^{\text {th }}$ century. ${ }^{37}$

Using these data one can trace the expenditure of the imperial treasuries on welfare provision. As Figure 1 below shows, the answer is not much. The $18^{\text {th }}$ century Spanish American fiscal state did have some rudimentary welfare structures to look after its own officials, or more precisely their families. Much of these funds were part of the montepios which the viceroys in Peru and Mexico had introduced in the 1760s as a version of the same institutions created in the Iberian peninsula. ${ }^{38}$ As Viceroy Amat y Junient in Lima argued some of the provisions of the European institutions had to be adapted to the American

36 Herbert S. Klein, The American Finances of the Spanish Empire. Royal Income and Expenditures in Colonial Mexico, Peru, and Bolivia, 1680-1809 (Albuquerque: University of New Mexico Press, 1998); Herbert S. Klein, Las Finanzas Americanas Del Imperio Español: 1680-1809 (México, D.F.: Instituto de Investigaciones Dr José María Luis Mora: Universidad Autónoma Metropolitana-Iztapalapa, 1994).

37 Regina Grafe and Alejandra Irigoin, "The Spanish Empire and Its Legacy: Fiscal ReDistribution and Political Conflict in Colonial and Post-Colonial Spanish America," Journal of Global History 1, 2 (2006); Regina Grafe and Alejandra Irigoin, "A Stakeholder Empire: The Political Economy of Spanish Imperial Rule in America,” Economic History Review 65, 2 (2012); Alejandra Irigoin and Regina Grafe, "Bounded Leviathan: Fiscal Constraints and Financial Development in the Early Modern Hispanic World," in Questioning Credible Commitment. Perspectives on the Rise of Financial Capitalism, ed. D'Maris Coffman, Adrian Leonard, and Larry Neal (Cambridge: Cambridge University Press, 2013); Alejandra Irigoin and Regina Grafe, "Bargaining for Absolutism. A Spanish Path to Empire and Nation Building," Hispanic American Historical Review 88, 2 (2008).

38 Note that these were different from the Montes de Piedad mentioned below, which provided small loans against real collateral. 


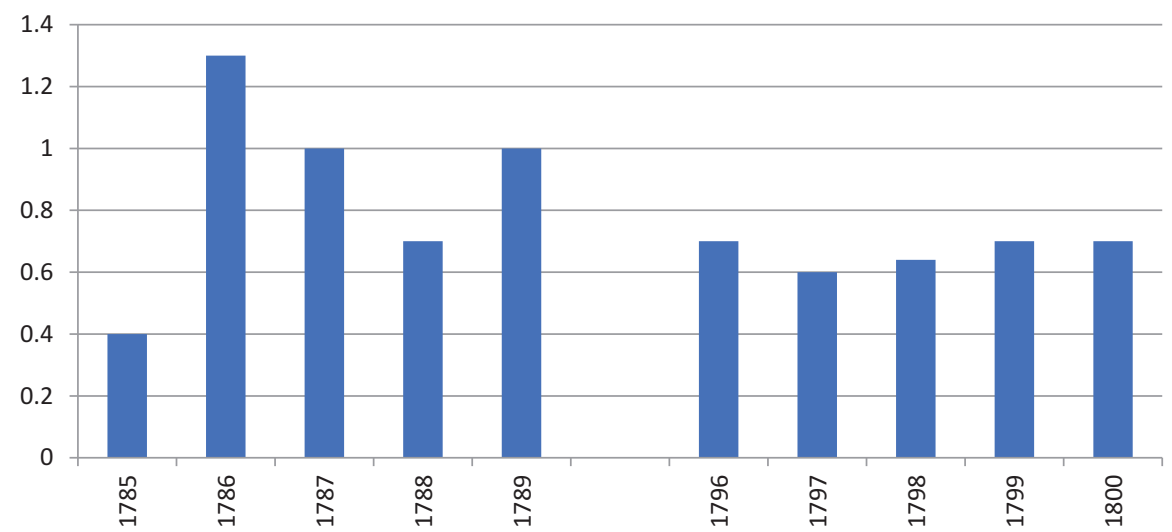

Figure 1: Welfare expenditure as \% of total expenditure across all Spanish American treasuries 1785-1800.

Source: See dataset (Grafe and Irigoin 2012).

context. ${ }^{39}$ However, overall the purpose was clearly identical to that which had led to the introduction of the institution in the peninsula, namely to look after the surviving next of kin of royal officials, normally widows and young children. The Monarchy would provide something like a basic life-insurance for most of its medium to higher level officials. Alas, it would not do so at its own expense, or in any case at that of other tax-payers. Instead, the montepios were mostly financed by contributions from living office holders and supposed to be self-financing. Thus they corresponded more to a modern compulsory life insurance scheme for dependents than a paternalistic welfare provision by the monarchy. ${ }^{40}$ And at 0.5 to 1.3 percent of the total expenditure of the Spanish American treasuries they were hardly a large scale expenditure item.

The purpose of such welfare was to guarantee the loyalty of the officers of the state but also to defend the social status of European and Euro-descendent populations within colonial society, where visibly impoverished families of deceased royal officials would have upset the social order. In other words, these

39 Miguel de Amat y Junient, Reglamento Para El Gobierno Del Monte Pio De Viudas, Y Pupilos, De Los Ministros De Las Audiencias, Tribunales De Cuentas, Y Oficiales De La Real Hacienda, De La Comprehension De Este Vireynato Del Peru: Resuelto Por Su Magestad, Que Dios Guarde, En Real (Lima: 1764).

40 Miguel de Amat y Junient, Memoria De Gobierno. Edicion Y Estudio Preliminar De Vicente Rodriguez Casado Y Florentubi Perez Embid (Sevilla: Escuela de Estudios Hispano-Americanos de Sevilla); Amat y Junient, Reglamento Para El Gobierno Del Monte Pio De Viudas, Y Pupilos, De Los Ministros De Las Audiencias, Tribunales De Cuentas, Y Oficiales De La Real Hacienda. 
were the local imperial institutions looking after their own in a narrow sense rather than a wider subject population. Montepios can hardly be read as the policies of an imperial bureaucracy with a bad conscience or at least a consciousness that the population at large had to be well governed and looked after.

This raises, however, the bigger issue of the material conditions of the vast majority of his Majesty's subjects in Spanish America. The point is important precisely because the historiography has taken the extractive nature of empire as part of the very definition of empire as we have seen in the case of Burbank and Cooper. The early modern Spanish empire has always been described as particularly extractive in nature, focused as it allegedly was on mining and mineral extraction to a European metropolis. The legacy of supposedly extractive Spanish colonial institutions is at the core of some of the most influential contributions to the question of modern economic well-being such as Acemoglu and Robinson's Why Nations Fail or Mahoney's Colonialism and Postcolonial Development. ${ }^{41}$ These have set off an intense debate about fiscal structures, political institutions, governance practices, labor regimes, and trade regulations that goes beyond the scope of this article. ${ }^{42}$

At least the question of a potential "colonial subsidy," i. e. the extraction of tax revenue from the colonies to the European territories, however, can in fact be answered conclusively using the same data introduced above. The results of research done by Irigoin and myself are relatively straightforward. ${ }^{43}$ The Spanish treasuries in America raised as much in per capita taxes by the late $18^{\text {th }}$ century as did for example peninsular Spain or contemporary metropolitan France. This was a capable tax state by the standards of the time. But only a modest share of the American revenues was transferred to European Spain as can be seen in Figure 2, falling from just under 12 percent in the early $18^{\text {th }}$ century to less than four percent over the course of the century. To the extent that one looks at a narrow definition of colonial extraction as a transfer of resources from the colonial sphere to a supposed metropolis, the notion of extractive Spanish colonial governance is a chimera.

This conclusion is reinforced when one keeps in mind the relatively modest size as a share of the overall economy of the tax take in all early modern policies,

41 James Mahoney, Colonialism and Postcolonial Development: Spanish America in Comparative Perspective (Cambridge; New York: Cambridge University Press, 2010); Daron Acemoglu and James A Robinson, Why Nations Fail? The Origins of Power, Prosperity, and Poverty (New York: Crown, 2012).

42 For a survey see Regina Grafe and Jorge M. Pedreira, "New Imperial Economies," in The Iberian World, ed. Fernando J. Bouza Alvarez, Pedro Cardim, and Antonio Feros (Routledge, 2019).

43 Grafe and Irigoin, "Legacy;" Grafe and Irigoin, "Stakeholder;" Irigoin and Grafe, "Bargaining for Absolutism." 


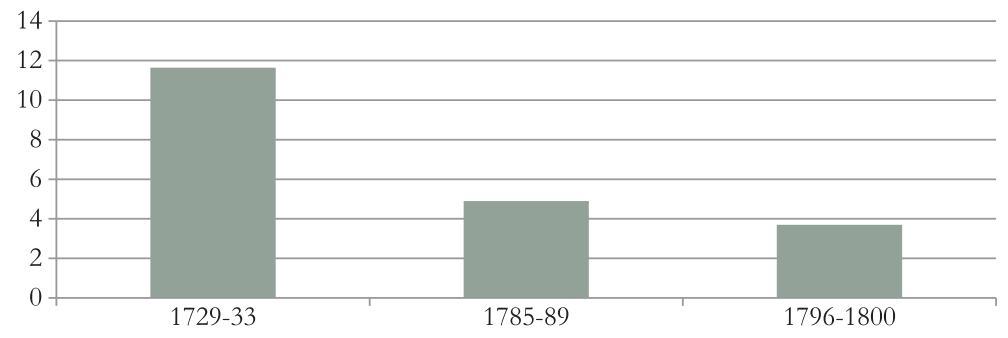

Figure 2: Transfers of revenues from Spanish America to Spain (share of total). Source: see dataset in (Grafe and Irigoin 2012).

even if in Spanish America it increased dramatically over the course of the $18^{\text {th }}$ century albeit from a very low starting level. Arroyo Abad and van Zanden have argued that the Spanish American transfers of resources towards the European part of the Empire shown in Figure 2 would be equivalent to about one or two percent of GDP. For comparison they contrast this with the much more excessive extraction of a "colonial subsidy" by the Dutch from Indonesia in the $19^{\text {th }}$ century, which they estimate as four to eight percent of Indonesian GDP. One would want to understand any measures of the size of the colonial economy as a guestimate only. However, as orders of magnitude go it is now well established that the Spanish Empire in the Americas was not an extractive polity in the fiscal sense before the $19^{\text {th }}$ century either in comparison to European polities or to other empires.

The data provide empirical evidence that Burbank's and Cooper's definition of empires as necessarily being driven by the extraction of resources is indeed problematic. In polycentric imperial structures governance practices aimed at reducing potential opposition by local elites were the better strategy for guaranteeing the survival of empire and hegemonic rule. ${ }^{44}$ Extraction to a metropolis stood in the way of such structures and needed to be avoided. However, it should be noted that this did not mean that the Spanish empire was not relying on extractive practices. Rather, the beneficiaries were overwhelmingly the local elites in the Americas rather than the peninsula. The ideology of the far-flung empire served to legitimate economic rent-seeking at the hands of local and regional elites. Extraction in Spanish America was a political practice of local elites first and foremost rather than of a faraway imperial power.

44 Regina Grafe and Alejandra Irigoin, "Bounded Leviathan: Fiscal Constraints and Financial Development in the Early Modern Hispanic World," in Questioning Credible Commitment: Perspectives on the Rise of Financial Capitalism, eds. D'Maris Coffman, Larry Neal, and Adrian Leonard (Cambridge: Cambridge University Press, 2013). 
A last set of data can help to further contextualize charity within the existing socio-economic realities in colonial Spanish America. Economic historians use so-called welfare ratios to estimate the material well-being of past populations. The idea is that a consumption basket is assembled that represents a "barebones" survival level in terms of the need for food, shelter, and clothing. ${ }^{45}$ That basket is then compared to the wages of workers to understand how close to the subsistence level, represented by an index of 1 , they were. Figure 3 reports a set of recent estimates across various colonial Latin American cities. For context Madrid is included. The results of this study and others using slightly different methodologies are yet again that the colonial realm should not be seen as an exceptionally tough environment. ${ }^{46}$ Life was hard for humble peasants and urban workers. But it was not systematically harder in the Americas than in

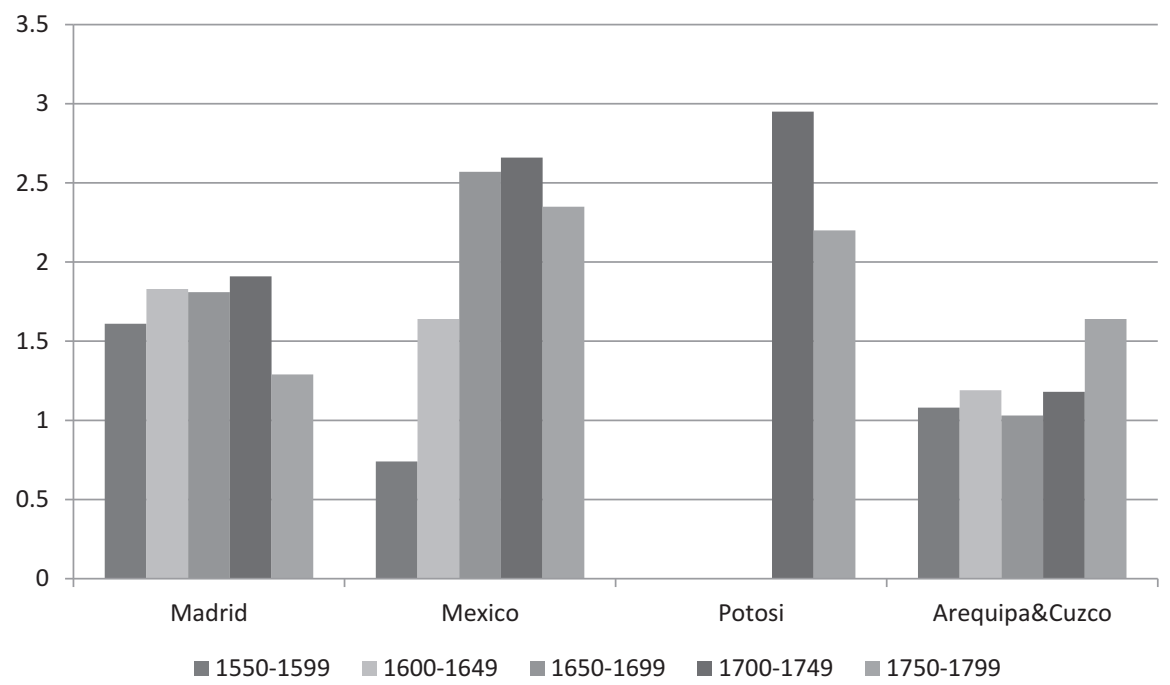

Figure 3: Living standards in colonial Spanish America (welfare ratios). Source: (Arroyo Abad, et al. 2012).

45 For the technique see Robert C. Allen, "The Great Divergence in European Wages and Prices from the Middle Ages to the First World War," Explorations in Economic History 38, 4 (2001).

46 Leticia Arroyo Abad and Jan Luiten van Zanden, "Growth under Extractive Institutions? Latin American Per Capita Gdp in Colonial Times," Journal of Economic History 76, 4 (2016); Leticia Arroyo Abad, Elwyn Davies, and Jan Luiten van Zanden, "Between Conquest and Independence: Real Wages and Demographic Change in Spanish America, 1530-1820,” Explorations in Economic History 49, 2 (2012); Leticia Arroyo Abad and Jan Luiten van Zanden, "Optimistic but Flawed? A Reply," Revista de historia Economica/Journal of Iberian and Latin 
Iberia. Instead differences across the colonial realm were larger than those between the Americas and Iberia. There is reason to assume that living standards in the southern Peruvian Andes were particularly poor, while populations in Mexico or Upper Peru (Bolivia) fared relatively better at least until the very late $18^{\text {th }}$ century. ${ }^{47}$ Welfare ratios that double subsistence needs probably meant that even in bad years basic needs were covered. Indeed, we know that famines were quite rare in colonial Spanish America.

Overall the material conditions within which charity operated in colonial Spanish America were in many ways comparable to those in southern Europe at the same time. We would do well to not simply equate empire with extractive institutions. There is now sufficient evidence for Spanish America to seriously question the notion that there was an imperial core that systematically extracted large amounts of resources from an imperial periphery. In terms of material conditions differences within the empire were larger than those between colonial territories and European ones. Polycentric empire created thus an interesting contradiction. The expansion of power beyond the original legitimization necessitated political practices that were broadly consensus seeking and could represent a notion of good governance mostly through decentralization. Empowered local elites in the Americas were the empires' strongest support. Yet, they were also the sources of extraction of rents from American populations at large. Charity provided by elites and their extractive capacity should thus be understood as the two sides of the same coin.

\section{III}

Even without extraction to a colonial center there was plenty of want and misery in colonial Spanish America. Humboldt noted in 1803 that "the streets of Mexico swarm with from twenty to thirty thousand wretches," most of whom were

American Economic History 33, 1 (2015); Rafael Dobado González and Hector García Montero, "Colonial Origins of Inequality in Hispanic America? Some Reflections Based on New Empirical Evidence," Revista de Historia Economica / Journal of Iberian and Latin American Economic History 28, 2 (2010); Rafael Dobado González, "Pre-Independence Spanish Americans: Poor, Short and Unequal ... or the Opposite?," Revista de Historia Economica / Journal of Iberian and Latin American Economic History 33, 1 (2015).

47 For a social history of one Potosi in the $16^{\text {th }}$ and $17^{\text {th }}$ century see e. g. Jane E. Mangan, Trading Roles: Gender, Ethnicity, and the Urban Economy in Colonial Potosí (Durham, N.C.: Duke University Press, 2005). 
reduced to passing the night sub dio, under god's sky. ${ }^{48}$ Various estimates in the late $18^{\text {th }}$ century placed the number of indigents anywhere between 15 or 25 percent of the population of Spanish America's largest city. ${ }^{49}$ City fathers in Mexico City and elsewhere reacted to this with initiatives to expand both traditional charity and more controlling urban welfare means at least in part inspired by ideas of the Enlightenment. Alms giving was encouraged, but the city also expanded the tobacco workshop meant to employ the poorest in the late $1760 \mathrm{~s}$ and opened a Poor House in 1774. The impressive building of the Monte de Piedad, a not for profit pawnbroker with strong religious links, still overlooks the Mexico Zócalo today. It was meant to allow the lower strata of society to find interest free credit in hard time and escape less scrupulous lenders, while encouraging them to pray for their souls.

Material conditions in Mexico tightened in the late $18^{\text {th }}$ century after a century of very notable growth. ${ }^{50}$ But poverty reflected inequality as much as deteriorating general economic conditions. It is worth remembering that as societies become overall better off their potential degree of inequality increases. This is often described as the Inequality Possibility Frontier. The intuition is simple. In a society that is collectively at the subsistence level next to nothing can be taken away from the politically weak and given to the strong without endangering the very survival of the weak. As overall wealth increases the scope for a more skewed distribution of resources also increases. ${ }^{51}$ But in pre-industrial societies the extraction rate, that is how much of the economic pie the elites managed to monopolize, could in fact be very high, even if inequality was moderate. Put simply, inequality was potentially the largest threat to social peace.

Inequality in Spanish America was local and regional as shown above. And while the fiscal governance structure of the Empire did not result in large-scale extraction to a supposed metropolis, it had become over time as system of redistribution of resources within Spanish America of gigantic proportions. Figure 4. below reproduces the figures for transfers to Spain shown in Figure 2. But it compares those with the share of revenues collected in particular districts in Spanish America and transferred to other fiscal districts within

48 Alexander von Humboldt and John Black (Trans.), Political Essay on the Kingdom of New Spain (New York: AMS, 1966). cited in Arrom, Containing the Poor, 5-6.

49 Arrom, Containing the Poor, 6.

50 Amilcar Challu, “Grain Markets, Food Supply Policies and Living Standards in Late Colonial Mexico” (PhD, Harvard, 2007); Dobado González, "Pre-Independence Spanish Americans: Poor, Short and Unequal ... or the Opposite?," table 2.

51 Branko Milanovic, The Have and the Have-Nots: A Short and Idiosyncratic History of Global Inequality (New York: Basic Books, 2011). 


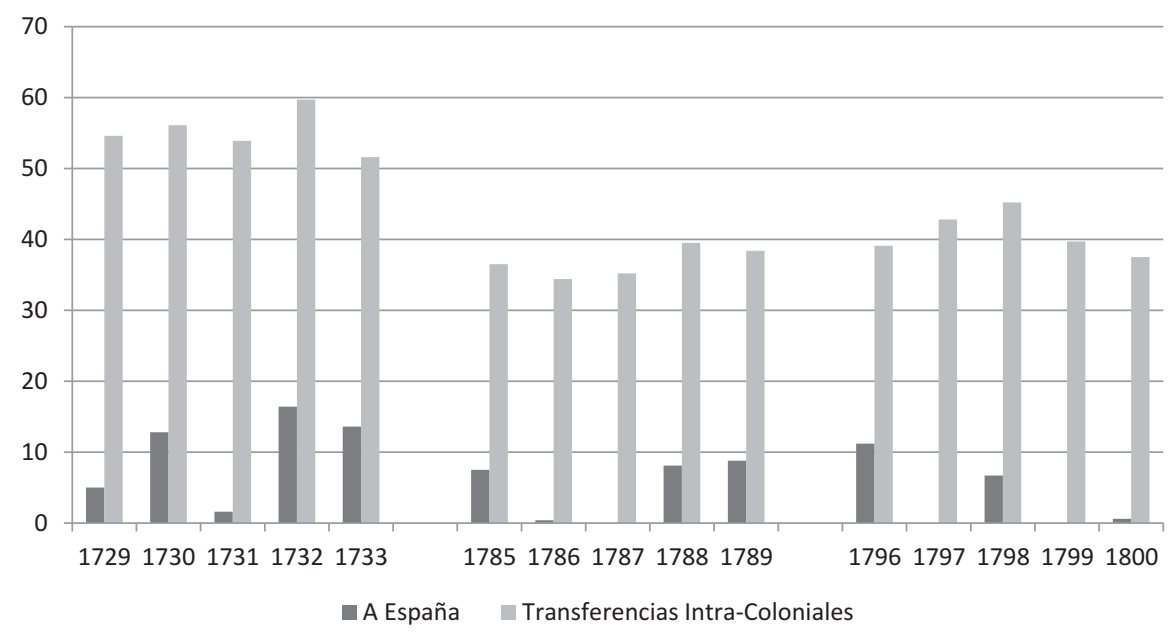

Figure 4: Intra-Colonial transfers and transfers to Spain 1729-1800.

Sources: see dataset in (Grafe and Irigoin 2012).

Spanish-American. As is evident in most years 40 to 50 percent of SpanishAmerican revenues were transferred outside the region where they had been collected. The logical result was that some districts had more funds available than they collected, while others were net exporters of capital.

There is no need here to explain the genesis of this peculiar colonial fiscal system, which has been analyzed in detail elsewhere. ${ }^{52}$ The same is true for the financial architecture underpinning it. ${ }^{53}$ But a few key elements of the system are crucial in order to understand the link between imperial fiscal practices and charity in colonial Spanish America. The massive redistribution of funds between Spanish American regions affected through the means of the fiscal system made some regions poorer and others richer. It was overwhelmingly controlled by local elites, whose needs for trade finance and investment opportunities it served. It also provided liquidity for merchants, miners, and the agricultural sector. For all practical purposes it fulfilled one of the most important functions usually associated with the banking sector, namely the transfer across spatial units between regions that suffered from a scarcity of investable capital to those that had a surplus. The corporate bodies organizing miners and

52 Grafe and Irigoin, “Legacy”; Grafe and Irigoin, "Stakeholder”; Irigoin and Grafe, "Bargaining for Absolutism.”

53 Regina Grafe, "An Empire without Debt? The Spanish Empire and Its Colonial Realm," in A World of Public Debts: A Global Political History, eds. Nicolas Barreyre and Nicolas Delalande (forthcoming). 
merchants (consulados, tribunals de comercio y mineria) in turn provided syndicated loans to the public treasuries. In so doing they fulfilled a second function usually associated with the banking system, the ability to overcome the time inconsistency between revenue and expenditure by drawing on credit.

The peculiar fiscal-financial colonial Spanish system had a third element. While fiscal governance structures provided for interspatial flows of capital and professional corporations were fundamental in organizing large-scale public finance, religious and charitable institutions were the local backbone of credit intermediation in Spanish America. Banking, credit, and charitable giving were intricately linked into one material caritative complex. Endowments being given to religious institutions but also occasionally to urban ones for charitable purposes were a common feature of early modern society. Confraternities, hospitals, convents, and monasteries all depended on alms and in particular on large-scale donations for their material basis. In this, Spanish religious foundations had more than a passing resemblance with Islamic waqf. Religious endowments with charitable purposes had a long tradition in all catholic and Orthodox Christian territories. However, in contrast to Italy or France the economic activities of Hispanic religious and charitable institutions either side of the Atlantic came to turn into large-scale banking activities. Religious institutions dominated credit mediation and provision in the Hispanic reigns like in no other Christian polity. Unlike in other catholic countries competition from private banks or notaries acting as credit intermediaries was also rarely important. Unlike waqf Hispanic religious and charitable endowments faced virtually no restriction to lending at interest or investing in any matter of economic activity.

Thus the basic operation of religious confraternities across Spanish America was to collect and accumulate substantial funds through membership fees and much more through donations, invest these, and finance religious and charitable activities with the income from those funds. The statutes of the cofradia del Rosario de Toluca read

whenever there should be left-over funds after the ordinary expenditure is paid the mesa [leadership] should try to invest these in valuable properties to their satisfaction and with greatest security so that at all times they support ... the capital and interest, and with that it shall be possible to fulfil exactly the objectives of the pious works and commitments ... ${ }^{54}$

Other religious institutions, convents, monasteries, cathedral chapters, and the tribunals of the Inquisition operated in the same way. Their financial acumen differed vastly. The pioneer studies of Lavrin had suggested that many convents managed their moneys poorly, but most recent historians have found astute

54 Cited in Mejía Torres, Las Cofradias Del Valle De Toluca, 141. 
financial management. ${ }^{55}$ Most institutions were also increasingly embedded in a structure of financial oversight. Religious orders sometimes had auditing practices inside the order, Inquisition tribunals were subject to regular checks of their books, and religious confraternities were controlled by local bishoprics, cabildos ecclesiasticos, or church courts. ${ }^{56}$

They were also ubiquitous and covered all walks of life. In the late $18^{\text {th }}$ century a survey of confraternities found 941 confraternities in the Archbishopric of Mexico alone. ${ }^{57}$ Most had restrictions as to who could join that were based on professional activities or castas. In line with corporate society but somewhat surprising from a point of view of racial attitudes the latter were not hierarchical. Confraternities of indigenous people for example had explicit statutes to exclude non indigenous populations from their activities. The cofradía de la Purisima Concepción de Nuestra Señora en Cuauhtitlán ordered that for the funeral of its members there should be only "indios, y sin españoles, negros, mestizos, mulatos, ni chinos." 58

Religious institutions accumulated wealth through donations in cash and in kind and through direct investment in houses, farms, mercantile activities, and public debt instruments. Credit was given at the standard rate of 5 percent, only among religious institutions the lower rate of 2.5 percent was sometimes observed. One might think about that as a form of interbank lending. ${ }^{59}$ Much of what we know about these institutions' finances results from the accounts that were compiled in repeated rounds of disentailment beginning in the late $18^{\text {th }}$ century and in particular in the early $19^{\text {th }}$. Figure 5 below shows the composition of the capital reported

55 Asunción Lavrín, "The Role of Nunneries in the Economy of New Spain in the Eighteenth Century," Hispanic American Historical Review 46 (1966); Kathryn Burns, Colonial Habits: Convents and the Spiritual Economy of Cuzco, Peru (Durham [N.C.]: Duke University Press, 1999); Gisela von Wobeser, "La Fundaciones Piadosas Como Fuentes De Crédito En La Época Colonial," Historia Mexicana 38, 4 (1989); Gisela von Wobeser, "La Inquisicion Como Institucion Crediticia En El Siglo Xviii,” Historia Mexicana 39, 4 (1990); Gisela von Wobeser, "La Fundacion De Capellanias De Misas, Una Costumbre Arraigada Entre Las Familias Novohispanas. Siglo Xvi-Xviii," Jahrbuch für Geschichte von Staat, Wirtschaft und Gesellschaft Lateinamerikas 35 (1998); Gisela von Wobeser, El Crédito Eclesiástico En La Nueva España. Siglo Xviii, 2 ed. (Mexico: Fondo de cultura económica, 2010); Asuncion Lavrin, "El Convento De Santa Clara De Queretaro: La Administracion De Sus Propiedades En El Siglo Xvii,” Historia Mexicana 25, 1 (1975). For a more economic analysis in the peninsula Cyril Milhaud, "Priests or Bankers? The Ecclesiastical Credit in Modern Spain,” Working paper hal-01180682 (2015).

56 Bazarte Martínez, Las Cofradias.

57 Ibid., 46.

58 Only Indians and without Spaniards, blacks, mixed race people, or Chinese. Cited in ibid., 60 .

59 Ibid., 158. 


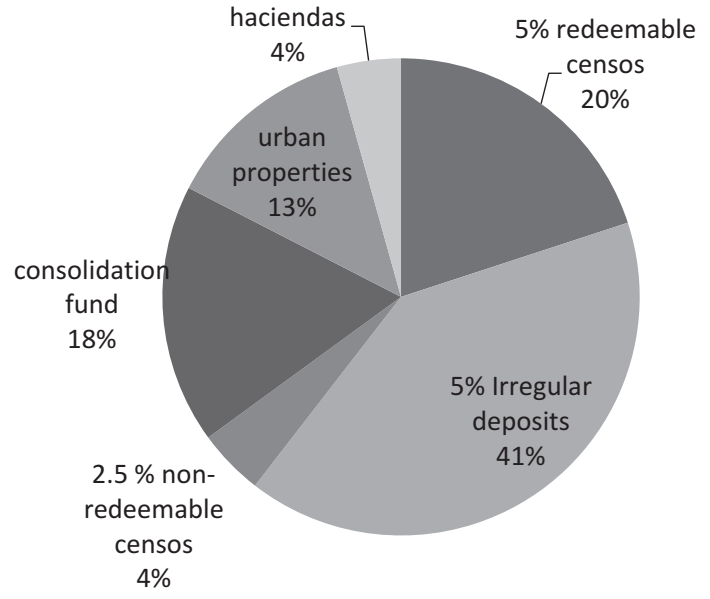

Figure 5: Capital of the llustre Archicofradia del Santisimo Sacramento y Caridad (Mexico) in 1826.

Source: (Bazarte Martínez 1989).

by one of the most prosperous confraternities of Euro-descendants in Mexico City, the confraternity of the Holy Sacrament and Charity. More than three fifth of its very substantial capital was invested in so-called censos (collatoralized loans) and irregular deposits given to private individuals, mercantile houses, miners, or agricultural investors. These produced the customary 5 percent interest rate. A small amount was lent to other religious institutions at half that interest rate. 20 percent had been turned over to a consolidation fund, an expropriatory measure imposed during the financial chaos of the very late colonial period. ${ }^{60}$ Just under one fifth was invested in urban properties and rural haciendas. For all practical purposes religious institutions were very much like modern charitable endowments. Money or sometimes property, which was pledged by individuals seeking to do charitable work, was lent out at interest to third persons. The resulting interest payments in turn supported practically the entire charitable and religious life of colonial Spanish America.

What was true for confraternities was equally the case for other welfare institutions such as the Mexico poor house. Figure 6. depicts its sources of income again for the very late colonial period. The investments of the poor house were substantial. Three quarters were concentrated in participations in loans syndicated by the large corporations of miners and merchants, which collected investments from a variety of religious and sometimes private investors, and bundled those into large investments in tax collection, tobacco rents,

60 Gisela von Wobeser, "La Consolidación De Vales Reales Como Factor Determinante De La Lucha De Independencia En México, 1804-1808,” Historia Mexicana 56, 2 (2006). 


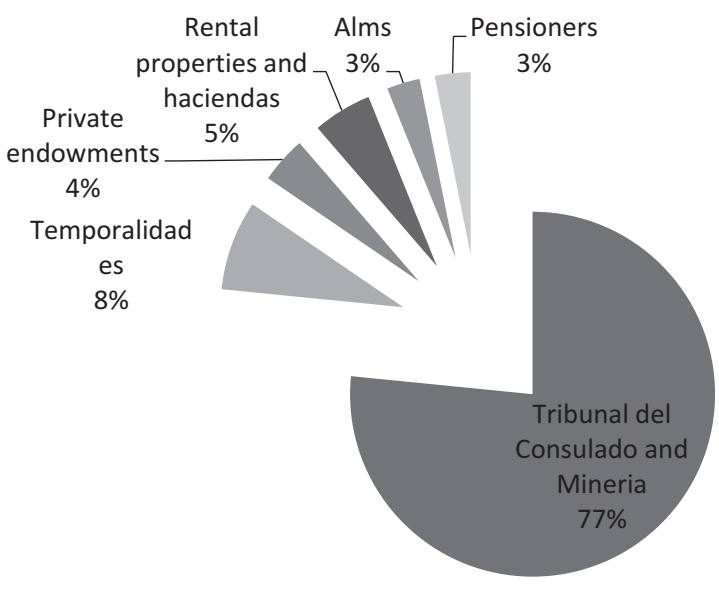

Figure 6: Sources of income of the Mexico poor house 1826 for 1811.

Source: (Arrom 2000, 161).

and substantial loans to the public purse. The poor house also benefited from some funds that had belonged to the Jesuits (temporalidades) expelled a quarter of a century earlier, smaller private endowments, and some rental property. Only 3 percent of its income was derived from alms. And its pensioners, elderly and fray people who had enough money to pay for being looked after in the poor house, contributed another modest 3 percent.

While the concrete investment portfolios of charitable institutions in Spanish America differed significantly, the pattern is clear. The economy of welfare and religious charity in Spanish America was corporate in both meanings of the word. It was deeply embedded in the corporate logic of colonial society that made religious corporations and collectives part of the imperial structure of governance. The charity they provided fulfilled imperial needs for good governance legitimizing the hegemony of local elites. The money they collected offered everyone in colonial society with a little capital to spare to work on their salvation. The salvation of a sinner's soul in turn became the material support for the ill, the poor, and the disabled. It also became the investable capital employed by merchants, miners, and hacendados in their economic activities. It was thus also corporate in a more modern, capitalist way. What Arrom has called the financial partnership of Church, state, and private philanthropy provided for a well-capitalized and capitalist charitable sector of the colonial economy and society. ${ }^{61}$

61 Arrom, Containing the Poor, chapter 2. 


\section{IV}

In Spanish America there was nothing oxymoronic about empire and charity. They were in the literal sense two sides of the same coin. As I have argued the empire had a problem of legitimizing rule once it had extended its reach beyond the original sphere of political legitimization. Good governance was more than a discursive element used by conquered and conquerors alike. In a society that relied on institutionalized difference across corporate collective groups it was the means to justify imperial rule. The empire was not particularly extractive in terms of transfers to a supposed metropolis. The idea of the Spanish empire as an extractive structure in terms of a colonial subsidy is largely fiction. Yet, because the empire relied on polycentric structures that strongly empowered local elites it incurred in a contradiction. Powerful local elites could delegitimize the empire through local and regional abuse of their power.

At the local and regional level charity was an integral part of imperial practices of good governance. A material caritative complex sui generis linked the moral economy of charity, which legitimized local elites, with their own financing needs and those of the imperial polity via the financial acumen of religious and charitable institutions. Saving one's soul and investing in a profitable enterprise were not only no contradiction, they were aligned interests. Charitable activities sustained and reinforced the system of castas through separate institutions along racial/ethnic lines; they sustained gender and social status norms by confining women of poor repute and financing dowries for Euro-descendent girls; they reinforced the role of Catholicism as sustaining imperial rule by financing most of the lay public religious festivities, processions, and displays; they provided crucial welfare services in a mixture of membership-paid-for and charitable financing. At the same time, they financed the polity and the private sector and guaranteed the self-sufficiency of the basic welfare sector.

Historians have noted that the $18^{\text {th }}$ century drive to abandon indiscriminate charity in favor of educational and repressive measures to turn the poor into useful members of society advocated by those inspired by European enlightened writers had only limited success in the Americas. In Mexico City the poor inmates of the poor house were ultimately running the poor house and managed to fend off new-fangled ideas of well-meaning social reformers. ${ }^{62}$ Surely there were many reasons for this outcome. But one was that the existing system

62 Ibid. 
benefited very large parts of society, donors and recipients alike. The intermingling of religious, moral, economic, and social motives arguably created a stable system that underpinned colonial rule successfully until it was unraveled from the outside by the implosion of Spanish rule in the peninsula and from the inside by the abandonment of layered and fragmented forms of sovereignty in the transition to a republican order. 